\title{
CELSR2 wt Allele
}

National Cancer Institute

\section{Source}

National Cancer Institute. CELSR2 wt Allele. NCI Thesaurus. Code C140182.

Human CELSR2 wild-type allele is located in the vicinity of $1 \mathrm{p} 13.3$ and is approximately 26

$\mathrm{kb}$ in length. This allele, which encodes cadherin EGF LAG seven-pass G-type receptor 2 protein, is involved in cell-cell signaling. 